\title{
Evaluación de los parámetros mecánicos de una mezcla asfáltica sometida a las condiciones ambientales de la ciudad de Bogotá D.C.
}

\section{Evaluation of mechanical parameters of an asphalt mixture under the environmental conditions of Bogotá D.C.}

\author{
Hugo Alexander Rondón Quintana*1, Fredy Alberto Reyes Lizcano** \\ * Universidad Distrital Francisco José de Caldas, Bogotá D.C. COLOMBIA \\ ** Pontificia Universidad Javeriana. Bogotá D.C. COLOMBIA
}

Fecha de recepción: 22/ 08/ 2011 Fecha de aceptación: 13/ 03/ 2012 PAG. 57 - 74

Resumen

El artículo presenta el cambio que experimenta el módulo resiliente, la deformación permanente y la resistencia a fatiga de una mezcla de concreto asfáltico cuando es expuesta a las condiciones climáticas de la ciudad de Bogotá D.C. (Colombia) durante 47-48 meses. Las mezclas fueron fabricadas utilizando dos cementos asfálticos (CA) fabricados en Colombia: CA 80-100 y CA 60-70. La tendencia general de las mezclas con el tiempo de exposición es experimentar un aumento en los valores de rigidez debido principalmente a procesos de endurecimiento por envejecimiento del ligante asfáltico. El aumento en rigidez genera incremento en la resistencia al fenómeno de ahuellamiento y en la vida de fatiga de la mezcla analizada cuando ésta sea utilizada para conformar capas asfálticas gruesas en el pavimento. Con base en la evolución del módulo resiliente con el tiempo de exposición al medio ambiente se propone una ecuación para predecir de manera aproximada el cambio que experimenta la vida a fatiga de la mezcla.

Palabras Clave: Módulo resiliente, ley de fatiga, envejecimiento, mezcla asfáltica densa en caliente, cemento asfáltico

\begin{abstract}
The present paper introduces the evolution of resilient modulus, permanent strain and fatigue life of an asphaltic concrete mixture exposed under weather conditions in Bogota D.C. (Colombia) during 47-48 months. Mixtures were elaborated by using two asphaltic cements (CA) made in Colombia: CA 80100 and CA 60-70. Mixtures generally tend to increase their stiffness values after an exposure period, mainly due to hardening and ageing processes undergone by asphaltic binder. A stiffness gain leads to increase endurance against rutting phenomenon and fatigue life of the analyzed mixture employed to lay thick asphaltic layers on the pavement. Based on the resilient modulus evolution due to exposure under environmental conditions, an equation is proposed to approximately predict the evolution of fatigue life endured by a mixture.
\end{abstract}

Keywords: Resilient modulus, fatigue law, aging, hot asphalt mixture, asphalt cement

\section{Introducción}

\footnotetext{
1 Autor de correspondencia / Corresponding author:
} E-mail: harondonq@udistrital.edu.co

\section{Introduction}

The main degradation mechanisms intended to be controlled by empirical and mechanistic methodologies of pavement design are fatigue and the excess of permanent deformation on vertical road direction (rutting) (e.g., Shell, 1978; TAI, 1982; AUSTROADS, 1992; AASHTO, 1993, TRL, 1993; HMSO, 1994; Urban Development Institute and Universidad de Los Andes, 2002; MEPDG, 2004). Fatigue phenomenon caused by cyclic vehicular loads take place inside bonded layers. In the case of flexible structures, this phenomenon takes place because of high deformation values due to tensile stress in the lowest area of an asphaltic layer. The continuous vehicle traffic makes the asphaltic layer bending down thus generating tensile stresses in its lower area. 
Such repeated load stress causes a stiffness loss of the asphaltic mixture and provokes plastic deformations due to tensile stress, which in turn lead to micro-crackings. Because of continuous and repeated load stress and stiffness loss, micro-cracking coalescence takes place leading to the occurrence of a visible cracking (macrocracking). If the fatigue phenomenon occurs due to load stress, macro-crackings take place in the lower area of the asphaltic layer (which is the area where the tensile stress is higher). Macro-crackings are spread upwards to the road pavement surface where they are reflected as parallel crackings to the lengthwise carriage way direction, which under repeated traffic loads are spread creating angular pieces that develop a map-cracking appearance. If this phenomenon takes place due to temperature conditions, the crackings spreading effect occurs in the opposite way, thus micro-crackings are provoked from the grade line and they are spread towards the inner fiber in the asphaltic layer. On the other hand, rutting is the residual vertical deformation accumulated due to traffic load, which may cause structural or functional failures to the road pavement. In an asphaltic layer, this phenomenon is mainly controlled by means of its own mixture stiffness (dynamic or resilient modulus).

In Colombia there are few researches developed on asphaltic mixtures fatigue phenomena mainly because of the lack of appropriate equipment to conduct field and laboratory measurements and also due to a small budget for research purposes. Such situation explains the lack of knowledge on this subject and the lack of an appropriate model characterizing fatigue behavior from material properties (mechanical, chemical, rheological and physical point of view), environmental conditions and traffic behavior.

Generally, fatigue tests on asphaltic mixtures consist in placing a specific geometric sample under repeated and identical load stresses; in order to determine the number of load cycles the sample is able to endure (Di Benedetto and De la Roche, 2005). This number of load cycles endured before failure is known as fatiguelife. According to Epps and Monismith (1972), Rao Tangella et al. (1990) and Di Benedetto et al. (2004) Di Benedetto and De la Roche (2005), the fatigue response from asphaltic mixtures is mainly affected by: 
- Sample compactation methods.

- Loading mode and the type of test applied.

- Mixture design parameters.

- Variants associated with the environment.

A detailed reference about fatigue phenomenon on asphaltic mixtures may be consulted from González and Vásquez (2009).

On the other hand, the main factors affecting asphaltic mixtures durability, assuming they are properly constructed, are: ageing rate, and moisture damage (Airey, 2003). Therefore, an asphaltic mixture must be designed and constructed not only to endure traffic loads but also environmental conditions. Evaluating the influence of environmental conditions on this type of material behavior is not an easy task. Nowadays it is carried out by isolating every single component (water, temperature, ultra-violet rays, among others) to separately evaluate their influence on binder and mixtures (from a mechanical and chemical point of view) (Kemp and Predoehl, 1981; Welborn, 1984; Kim et al., 1987; Shiau et al., 1991; Bishara et al., 2000; Bocci and Cerni, 2000; Brown and Scholz, 2000; Khalid and Walsh, 2000; Khalid, 2002; Airey, 2003; Said, 2005; Shen et al., 2006). Additionally and generally, these researches employ test methods and equipment (e.g. thin-film-oven test TFOT, rolling-thin-film-oven test RTFOT, microwave ovens, automatic pressure aging vessels PAV), which can not fully reproduce the influence of each environmental component on mechanical and rheological properties of mixtures and asphaltic binders (Jemison et al., 1991; Choquet and Verhasselt, 1992; Kuppens et al., 1997; Verhasselt, 1997). Furthermore, a significant amount of researches tend to combine these tests and equipment to evaluate material properties changes under real environmental conditions (Jemison et al., 1991; Migliori and Corté, 1998; Montepara, 1999; Montepara and Giuliani, 2000; Airey, 2003). As a general conclusion these test methodologies are unable to reproduce real conditions endured by asphaltic mixtures in situ. A method to measure the environmental influence on the behavior of asphaltic mixtures is by developing segments test or tracks test at scale units. 
The limitation of these tests is their high cost and they can not directly or separately measure the influence of traffic loads and environmental conditions.

Consequently, this paper introduces a study that intends to evaluate the influence of environmental conditions in Bogota D.C (Colombia) on stiffness and fatigue strength of a dense hot asphaltic mixture type MDC-2 (as per specifications by INVIAS, 2007 - Roads National Institute). It was decided to analyze this type of mixture as it is commonly used to build tread layers, which are directly exposed to environmental conditions. In the same way, climatic conditions of Bogotá D.C. were chosen because the city is located in an area where the following environmental conditions are present during a given day: predominantly cold with minimum and maximum average temperatures of $5^{\circ} \mathrm{C}$ and $19^{\circ} \mathrm{C}$, respectively and; periodical rains at any moment in the same day. In order to accurately understand the environmental influence on the behavior of asphaltic mixtures, further researches will analyze different climate conditions. This paper introduces the results from the first 47-48 months of the project, which evaluates mixtures elaborated with the two CAs produced in Colombia: CA 60-70 and CA 80-100. Regarding climatic conditions, these binders are employed provided that yearly average temperature is higher and lower than $24^{\circ} \mathrm{C}$, respectively in the area where the asphaltic layer will be built (INVIAS, 2007).

In order to evaluate the environmental influence on the mixture mechanical parameters, dynamic characterization tests were developed, such as resilient modulus, permanent deformation strength and fatigue law. Fatigue tests were conducted under controlled stress. Table 1 summarizes the main differences observed between tests under controlled stress and controlled deformation. 
Tabla 1. Comparación de los ensayos bajo esfuerzo controlado y deformación controlada (Epps y Monismith, 1972;

Di Benedetto y De la Roche, 2005)

Table 1. Comparison between tests under controlled stress and controlled deformation (Epps and Monismith, 1972;

Di Benedetto and De la Roche, 2005)

\begin{tabular}{|c|c|c|}
\hline Parámetro/Parameter & Esfuerzo controlado/Controlled stress & Deformación controlada/Controlled deformation \\
\hline Evolución durante el ensayo & Aumento de la deformación & Disminución del Esfuerzo \\
\hline Evolution during the test & Deformation increase & Stress decrease \\
\hline Criterio usual de falla & Rotura de la muestra & Perdida de la mitad del esfuerzo inicial \\
\hline Usual failure criterion & Sample rupture & Loss of half initial stress \\
\hline Vida a la fatiga & Más corta & Más larga \\
\hline Fatigue-life & Shorter & Longer \\
\hline Dispersión de los resultados & Más baja & Más alta \\
\hline Dispersion of results & Lower & Higher \\
\hline Aumento de la temperatura & Disminución de la vida & Aumento de la vida \\
\hline Temperature increase & Life decrease & Life increase \\
\hline Aumento del modulo de rigidez & Aumento de la vida & Disminución de la vida \\
\hline Stiffness modulus increase & Life increase & Life decrease \\
\hline Efecto del tiempo de receso & Mayor efecto benéfico & Menor efecto benéfico \\
\hline Effect of recess time & Greater benign effect & Lower benign effect \\
\hline Duración de la propagación de las macro-fisuras & Corta & Larga \\
\hline Macro-cracking spreading duration & Short & Long \\
\hline Crecimiento del daño & Más rápido de lo que ocurre in situ & Más representativo de lo que ocurre in situ \\
\hline Damage growth & Faster than in situ & More representative than in situ \\
\hline
\end{tabular}

Presently the investigation team, under a doctorate level study, is evaluating the effect of each component of Bogota environmental conditions and the loads on the mixture chosen for this research. For this team it was important to get acquainted with the behavior of every environmental component, in order to clearly describe and understand the results provided by micro level studies (isolated components).

\section{Methodology}

Design of asphaltic mixtures and characterization of materials. The quarry rock aggregate used for the elaboration of asphaltic mixtures to be employed in Marshall Test (called briquettes) comes from "Subachoque" quarry (Cundinamarca, Colombia). The following tests were conducted on such materials, in accordance with specifications by the Roads National Institute (2007a): grading analysis on coarse and fine aggregates (INV. E213), fine aggregates absorption and specific weight (INV. E-222), coarse aggregates absorption and specific weight (INV. E-223), aggregates abrasion resistance (sizes lower than 3/4") by employing the Los Angeles apparatus (INV. E-218); Micro-Deval abrasion test (INV.E-238), strength loss test (INV.E-220), fractured particles (INV. E - 227), 
test to measure sand content (INV. E-133) and elongation - flattening indexes (INV. E-230). These test results are presented in table 2, which values meet the minimum quality standards established by INVIAS (2007) specifications for the elaboration of MDC-2 mixtures used for tread layers construction.

Tabla 2. Caracterización de los agregados

Table 2. Aggregates Characterization

\begin{tabular}{||l|c||}
\hline Ensayo/Test & Resultado/Result \\
\hline $\begin{array}{l}\text { Peso específico } \\
\text { Specific weight }\end{array}$ & 2.56 \\
\hline $\begin{array}{l}\text { Equivalente de arena } \\
\text { Sand Content }\end{array}$ & $\mathbf{8 6} \%$ \\
\hline $\begin{array}{l}\text { Caras fracturadas } \\
\text { Fractured faces }\end{array}$ & $\mathbf{9 2} \%$ \\
\hline $\begin{array}{l}\text { Índice de alargamiento } \\
\text { Elongation index }\end{array}$ & $\mathbf{1 0} \%$ \\
\hline $\begin{array}{l}\text { Índice de aplanamiento } \\
\text { Flattening index }\end{array}$ & $10 \%$ \\
\hline $\begin{array}{l}\text { Ataque en Sulfato de sodio } \\
\text { Sodium sulfate attack }\end{array}$ & $12.4 \%$ \\
\hline $\begin{array}{l}\text { Microdeval } \\
\text { Microdeval }\end{array}$ & $\mathbf{2 0 . 3} \%$ \\
\hline $\begin{array}{l}\text { Resistencia al desgaste máquina de los Ángeles } \\
\text { Abrasion resistance Los Ángeles apparatus }\end{array}$ & $22.5 \%$ \\
\hline
\end{tabular}

In order to characterize mixtures the following standard tests were conducted on asphaltic cements CA 80-100 and CA 60-70 according to (INVIAS 2007) specifications: penetration (ASTM D-5), dynamic viscosity (ASTM D-4402), ductility (ASTM D-113), solubility in trichloroethylene (ASTM D-2042), water content (ASTM D-95), softening point (INV. E-712), residual analysis after rolling-thin-film-oven test (RTFOT) ASTM D-2872). These tests results are presented in Tables 3 and 4 .

After analyzing tests conducted on quarry rock aggregates and on asphaltic cements, five briquettes were elaborated (compacted with 75 strikes per face) for each asphalt percentage between $4.5 \%$ and $6.5 \%$, in order to develop Marshal Design (INV. E748, INVIAS, 2007a), so as to determine the optimum asphalt content of the mixture. In order to meet INVIAS (2007) specifications and to elaborate asphalt mixtures type MDC-2, the original aggregates grading was modified by using as a reference the percentage average values from grading range, established by the specification for briquettes elaboration for Marshall Test. 
Evaluación de los parámetros mecánicos de una mezcla asfáltica/Evaluation of mechanical parameters of an asphalt mixture

Calculations obtained from Marshall Test are registered in Tables 5 and 6. The optimum percentages of asphaltic cements, according to data in tables 5 and 6 , are $5.3 \%$ and $5.6 \%$ for mixtures elaborated with $\mathrm{CA} 80-100$ and CA 60-70, respectively. These percentages meet the minimum requirements established by INVIAS (2007) specification for MDC-2 and traffic types NT1 and/or NT2 (low and medium traffic volumes).

Tabla 3. Características generales del cemento asfáltico

Table 3. General Characteristics of CA 80-100 asphaltic cement

\begin{tabular}{|c|c|c|c|c|}
\hline Ensayo/Test & Método/Method & Unidad/Unit & CA $80-100$ & Resultado/Result \\
\hline \multicolumn{5}{|c|}{$\begin{array}{l}\text { Ensayos sobre el asfalto original } \\
\text { Tests developed on original asphalt }\end{array}$} \\
\hline $\begin{array}{l}\text { Penetración }\left(25^{\circ} \mathrm{C}, 100 \mathrm{~g}, 5 \mathrm{~s}\right) \\
\text { Penetration }\left(25^{\circ} \mathrm{C}, 100 \mathrm{~g}, 5 \mathrm{~s}\right)\end{array}$ & ASTM D-5 & $0.1 \mathrm{~mm}$ & $80-100$ & 85 \\
\hline $\begin{array}{l}\text { Índice de penetración } \\
\text { Penetration index }\end{array}$ & INV. E-724 & - & $-1 /+1$ & -0.5 \\
\hline $\begin{array}{l}\text { Viscosidad absoluta }\left(60^{\circ} \mathrm{C}\right) \\
\text { Dynamic viscosity }\left(60^{\circ} \mathrm{C}\right)\end{array}$ & ASTM D-4402 & Poises & 1000 mín. & 1400 \\
\hline $\begin{array}{l}\text { Ductilidad }\left(25^{\circ} \mathrm{C}, 5 \mathrm{~cm} / \mathrm{min}\right) \\
\text { Ductility }\left(25^{\circ} \mathrm{C}, 5 \mathrm{~cm} / \mathrm{min}\right)\end{array}$ & ASTM D-113 & $\mathbf{c m}$ & 100 mín. & $>105$ \\
\hline $\begin{array}{l}\text { Solubilidad en Tricloroetileno } \\
\text { Trichloroethylene solubility }\end{array}$ & ASTM D-2042 & $\%$ & 99 mín. & $>99$ \\
\hline $\begin{array}{l}\text { Contenido de agua } \\
\text { Water content }\end{array}$ & ASTM D-95 & $\%$ & 0.2 máx. & $<0.2$ \\
\hline $\begin{array}{l}\text { Punto de inflamación COC } \\
\text { Flashpoint COC }\end{array}$ & ASTM D-92 & ${ }^{\circ} \mathrm{C}$ & 232 mín. & 295 \\
\hline \multicolumn{5}{|c|}{$\begin{array}{l}\text { Ensayos sobre el residuo luego del RTFOT } \\
\text { Test developed on residue after RTFOT }\end{array}$} \\
\hline $\begin{array}{l}\text { Pérdida de masa } \\
\text { Mass loss }\end{array}$ & ASTM D-2872 & $\%$ & 1.0 máx. & 0.2 \\
\hline $\begin{array}{l}\text { Penetración }\left(25^{\circ} \mathrm{C}, 100 \mathrm{~g}, 5 \mathrm{~s}\right) \\
\text { Penetration }\left(25^{\circ} \mathrm{C}, 100 \mathrm{~g}, 5 \mathrm{~s}\right)\end{array}$ & ASTM D-5 & $\%$ & 48 mín. & 65 \\
\hline
\end{tabular}

Tabla 4. Características generales del cemento asfáltico

Table 4. General Characteristics of CA 60-70 asphaltic cement

\begin{tabular}{|c|c|c|c|c|}
\hline Ensayo/Test & Método/Method & Unidad/Unit & CA 60-70 & Resultado/Result \\
\hline \multicolumn{5}{|c|}{$\begin{array}{l}\text { Ensayos sobre el asfalto original } \\
\text { Tests developed on original asphalt }\end{array}$} \\
\hline $\begin{array}{l}\text { Penetración }\left(25^{\circ} \mathrm{C}, 100 \mathrm{~g}, 5 \mathrm{~s}\right) \\
\text { Penetration }\left(25^{\circ} \mathrm{C}, 100 \mathrm{~g}, 5 \mathrm{~s}\right)\end{array}$ & ASTM D-5 & $0.1 \mathrm{~mm}$ & $60-70$ & 67 \\
\hline $\begin{array}{l}\text { Índice de penetración } \\
\text { Penetration index }\end{array}$ & INV. E-724 & - & $-1 /+1$ & -0.7 \\
\hline $\begin{array}{l}\text { Viscosidad absoluta }\left(60^{\circ} \mathrm{C}\right) \\
\text { Dynamic viscosity }\left(60^{\circ} \mathrm{C}\right)\end{array}$ & ASTM D-4402 & Poises & 1500 mín. & 1750 \\
\hline $\begin{array}{l}\text { Ductilidad }\left(25^{\circ} \mathrm{C}, 5 \mathrm{~cm} / \mathrm{min}\right) \\
\text { Ductility }\left(25^{\circ} \mathrm{C}, 5 \mathrm{~cm} / \mathrm{min}\right)\end{array}$ & ASTM D-113 & $\mathbf{c m}$ & 100 mín. & $>105$ \\
\hline $\begin{array}{l}\text { Solubilidad en Tricloroetileno } \\
\text { Trichloroethylene solubility }\end{array}$ & ASTM D-2042 & $\%$ & 99 mín. & $>99$ \\
\hline $\begin{array}{l}\text { Contenido de agua } \\
\text { Water content }\end{array}$ & ASTM D-95 & $\%$ & 0.2 máx. & $<0.2$ \\
\hline $\begin{array}{l}\text { Punto de inflamación COC } \\
\text { Flashpoint COC }\end{array}$ & ASTM D-92 & ${ }^{\circ} \mathrm{C}$ & 232 mín. & 275 \\
\hline \multicolumn{5}{|c|}{$\begin{array}{l}\text { Ensayos sobre el residuo luego del RTFOT } \\
\text { Test developed on residue after RTFOT }\end{array}$} \\
\hline $\begin{array}{l}\text { Pérdida de masa } \\
\text { Mass loss }\end{array}$ & ASTM D-2872 & $\%$ & 1.0 máx. & 0.4 \\
\hline $\begin{array}{l}\text { Penetración }\left(25^{\circ} \mathrm{C}, 100 \mathrm{~g}, 5 \mathrm{~s}\right) \\
\text { Penetration }\left(25^{\circ} \mathrm{C}, 100 \mathrm{~g}, 5 \mathrm{~s}\right)\end{array}$ & ASTM D-5 & $\%$ & 52 mín. & 70 \\
\hline
\end{tabular}


Tabla 5. Resumen del ensayo Marshall para mezcla asfáltica MDC-2 con CA 80-100

Table 5. Summary of Marshall Test for MDC-2 asphaltic mixture containing CA 80-100

\begin{tabular}{||c|c|c|c|c|c|c||}
\hline $\begin{array}{r}\text { CA } \\
{[\%]}\end{array}$ & $\begin{array}{c}\text { Peso unitario } \\
\text { Unit weight } \\
{\left[\mathrm{g} / \mathrm{cm}^{3}\right]}\end{array}$ & $\begin{array}{c}\text { Estabilidad } \\
\text { Stability } \\
(\mathrm{E})[\mathrm{kg}]\end{array}$ & $\begin{array}{c}\text { Vacíos en la mezcla } \\
\text { Mixture Voids } \\
{[\%]}\end{array}$ & $\begin{array}{c}\text { Vacíos en agregados } \\
\text { Aggregates Voids } \\
{[\%]}\end{array}$ & $\begin{array}{c}\text { Flujo (F) } \\
\text { Flow } \\
{[\mathrm{mm}]}\end{array}$ & $\begin{array}{c}\text { Relación } \\
\text { Relation } \\
\text { E/F [kg/mm] }\end{array}$ \\
\hline 4.5 & 2.21 & 710 & 7.63 & 17.52 & 3.33 & 213.09 \\
\hline 5.0 & 2.24 & 835 & 5.76 & 16.89 & 3.45 & 242.14 \\
\hline 5.5 & 2.24 & 853 & 5.09 & 17.33 & 3.51 & 243.48 \\
\hline 6.0 & 2.23 & 813 & 4.64 & 17.96 & 3.70 & 219.71 \\
\hline
\end{tabular}

Tabla 6. Resumen ensayo Marshall para mezcla asfáltica MDC-2 con CA 60-70

Table 6. Summary of Marshall Test for MDC-2 asphaltic mixture containing CA 60-70

\begin{tabular}{|c|c|c|c|c|c|c||}
\hline $\begin{array}{c}\text { CA } \\
{[\%]}\end{array}$ & $\begin{array}{c}\text { Peso unitario } \\
\text { Unit weight } \\
{\left[\mathrm{g} / \mathrm{cm}^{3}\right]}\end{array}$ & $\begin{array}{c}\text { Estabilidad } \\
\text { Stability } \\
(\mathrm{E})[\mathrm{kg}]\end{array}$ & $\begin{array}{c}\text { Vacíos en la mezcla } \\
\text { Mixture Voids } \\
{[\%]}\end{array}$ & $\begin{array}{c}\text { Vacíos en agregados } \\
\text { Aggregates Voids } \\
{[\%]}\end{array}$ & $\begin{array}{c}\text { Flujo (F) } \\
\text { Flow } \\
{[\mathrm{mm}]}\end{array}$ & $\begin{array}{c}\text { Relación } \\
\text { Relation } \\
\text { E/F }[\mathrm{kg} / \mathrm{mm}]\end{array}$ \\
\hline 5.0 & 2.24 & 1189 & 5.83 & 16.95 & 3.40 & 349.86 \\
\hline 5.5 & 2.25 & 1323 & 4.47 & 16.80 & 3.60 & 367.84 \\
\hline 6.0 & 2.25 & 1393 & 3.48 & 16.96 & 3.69 & 377.18 \\
\hline 6.5 & 2.26 & 1229 & 3.02 & 17.60 & 3.92 & 313.38 \\
\hline
\end{tabular}

Development phase. After applying Marshall Design, briquettes were elaborated (180 each per type of CA) with asphaltic mixture MDC-2 to be exposed under Bogota D.C environmental conditions, employing the optimum CA content. These samples were placed on a building roof in Bogota D.C.

During the first 47-48 months of the Project, every three months resilient tests and permanent deformation tests were developed on these briquettes, in order to evaluate the parameters evolution in relation to environmental exposure periods. Resilient modulus test (INV. E-749, INVIAS, 2007a) has been developed at three different temperatures $\left(10,20\right.$ and $\left.30^{\circ} \mathrm{C}\right)$, and load frequencies $(2.5,5.0$ and $10.0 \mathrm{~Hz})$ by using the Nottingham Asphalt Tester (NAT). The permanent deformation resistance test, under repeated load cycles, was conducted under $100 \mathrm{kPa}$ stress at 3600 load cycles in accordance with standard procedure by EN 12697-22 (CEN, 2005). By using these tests results, an empirical equation was developed in order to predict the strength evolution of the analyzed mixture, in relation to the exposure time period to environmental conditions. 
So as to evaluate environmental conditions influence of Bogota D.C. on fatigue strength in the studied mixture, two phases were developed.

1. Phase 1: 360 fatigue tests and resilient modulus were analyzed on asphaltic concrete mixtures type MDC-1, MDC-2 and MDC-3 (developed in accordance with INVIAS, 2007), which were elaborated with CA 80100 mixture. This analysis was developed in order to determine the evolution of mixtures fatigue strength under stiffness. Fatigue results were obtained by conducting tests with the indirect tensile method using a NAT apparatus, following the procedures established by the prEN 12697-24E (CEN, 2005) specification. The test temperature and load frequency were $20^{\circ} \mathrm{C}$ and $2.5 \mathrm{~Hz}$, respectively. Load type selected for this test was controlled stress. Samples dimensions for fatigue tests are the same as those in Marshall Briquettes.

The results from this phase were used to develop an empirical equation that relates the evolution undergone by fatigue-life of asphaltic concrete mixtures under stiffness.

2. Phase 2: By employing the equation developed from phase 1 results, and based on data from stiffness evolution of time-exposed MDC-2 mixture under environmental conditions, the fatigue strength increase endured by such mixture when exposed at climate conditions in Bogota D.C. was determined quite accurately.

\section{Results}

Figures $1 \mathrm{a}-\mathrm{b}$ present the evolution of initial resilient modulus $\left(E_{O}\right.$, in $\mathrm{MPa}$ ) of $\mathrm{MDC}-2$ mixture (elaborated with CA 80-100 and CA 60-70, respectively) at temperature $\left(\mathrm{T}\right.$, in $\left.{ }^{\circ} \mathrm{C}\right)$ and frequency load $(F$, in $\mathrm{Hz})$. $\mathbf{A}$ typical modulus increase is observed when load frequency is increased and temperature decreases in the test. This evolution may be mathematically represented by means of the empirical Equation (1). In order to employ this equation, it is necessary to identify six status variants obtained by means of regressions. In the case of the analyzed mixture, these variants are presented in Table 7. 
These variants do not deliver a defined physical meaning and they mainly change with the type of binder, grading and type of rock aggregate employed in the elaboration of mixtures. Load frequency $F$ in the Equation (1) may be translated as the vehicle speed $(V$, in $\mathrm{cm} / \mathrm{s})$ by means of equation (2) proposed by Lin (1989, 1989a).

$$
\begin{gathered}
E_{o}=\exp \left(a+b T^{2}\right)+\left[\exp (c+d \sqrt{T})+\left(e+f T^{3}\right) F\right] \sqrt[2]{ } \\
F=\frac{1}{2 \pi t_{c}} \quad t_{c}=\frac{L}{V} 10^{0.004 h}
\end{gathered}
$$

$t_{c}$ is loading time expressed in seconds for an in-motion vehicle at different depths ( $h$ in $\mathrm{cms}$ and measured from the pavement structure surface) and $L$ is the wheel rim length in contact with the road pavement (usually 30 cms).

Tabla 7. Variables para simular la rigidez de la mezcla MDC-2 en función de T y $F$ Table 7. Variants used to simulate MDC-2 mixture stiffness in function of $\mathrm{T}$ and $\mathrm{F}$

\begin{tabular}{||c|c|c|c|c|c|c||}
\hline CA & a & b & c & d & e & f \\
\hline $80-100$ & 8.78 & -0.0035 & 5.26 & -0.63 & 12.4 & $-1.75 e-4$ \\
\hline $60-70$ & 9.21 & -0.00214 & 3.4 & -0.31 & 14.9 & $-1.5 e-4$ \\
\hline
\end{tabular}

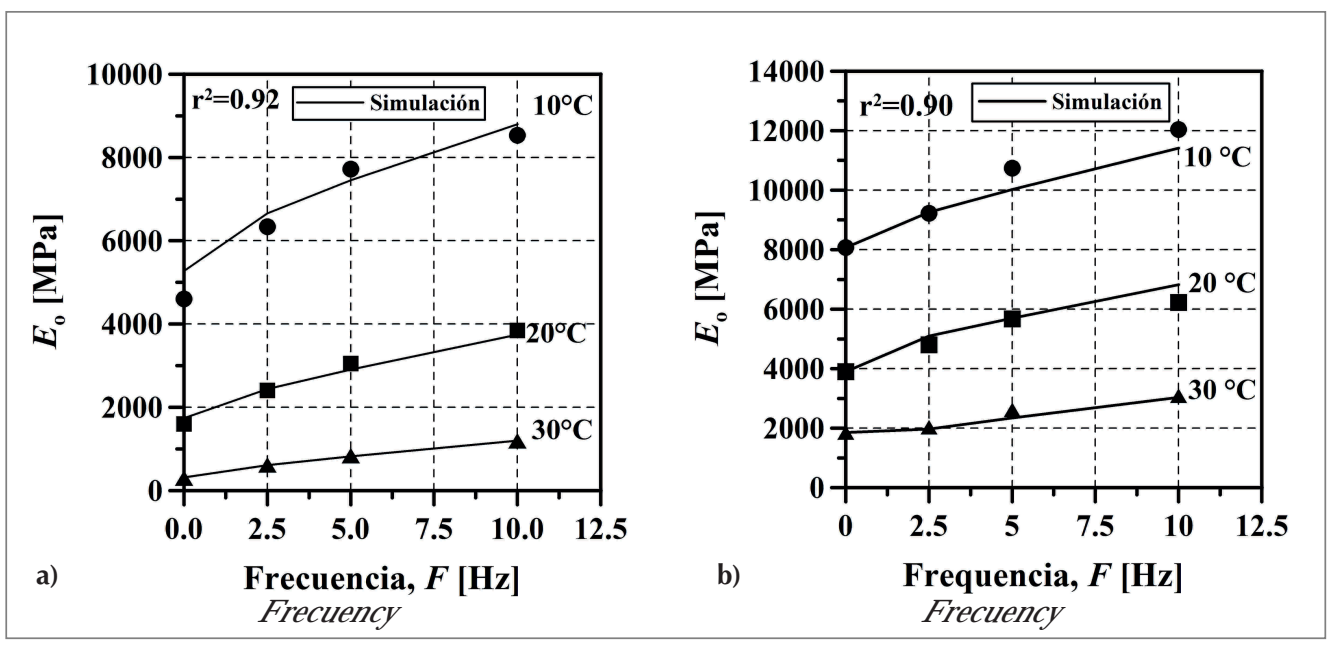

Figura 1. Evolución del módulo resiliente inicial $\left(E_{o}\right)$ de la mezcla $M D C-2$ con la temperatura $(\mathrm{T})$ y la frecuencia de carga (F). Mezcla fabricada con a) CA 80-100 y b) CA 60-70

Figure 1. Evolution of initial resilient modulus $\left(E_{o}\right)$ of MDC-2 mixture at temperature $(\mathrm{T})$ and load frequency $(\mathrm{F})$. Mixture elaborated from a) CA 80-100 y b) CA 60-70 
Figure 2 indicates the evolution of resilient modulus for asphaltic mixtures throughout time. Mixtures fabricated from CA 80-100 and CA 60-70 (Figures 2a and b, respectively) show a typical modulus increase when load frequency is incremented and test temperature is decreased. In mixtures fabricated from CA 80-100, the modulus tends to increase throughout exposure time under environmental conditions (see Figure 2a) and, therefore, permanent deformation strength increases (Figure 3). Such phenomenon takes place mainly due to oxidative ageing experimented by asphaltic cements due to temperature and ultra-violet (UV) radiation exposure effects.
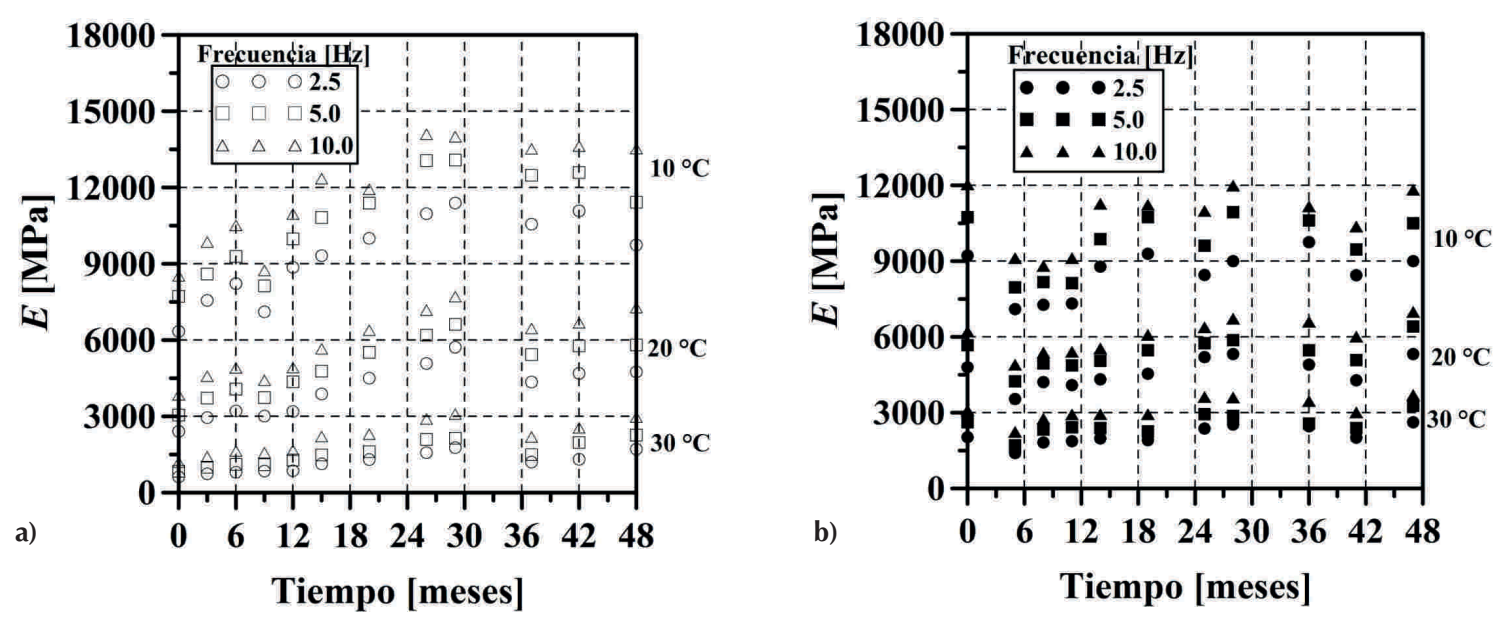

Figura 2. Evolución del módulo resiliente $(E)$ con el tiempo de envejecimiento $(t)$ para mezclas fabricadas con a) CA 80-100 y b) CA 60-70 Figure 2. Evolution of resilient modulus $(E)$ throughout ageing time $(t)$ for mixtures elaborated from a) CA 80-100 and b) CA 60-70

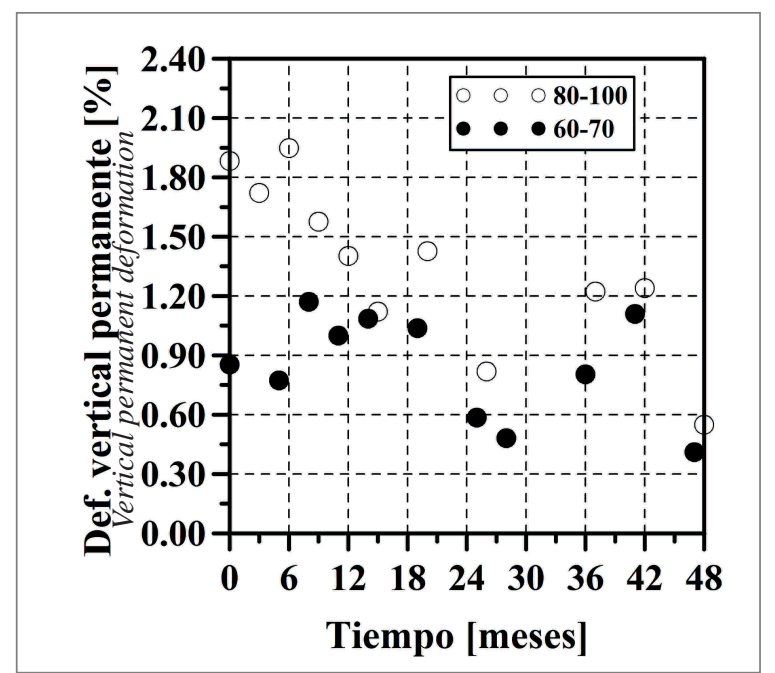

Figura 3. Evolución de la deformación vertical permanente con el tiempo de envejecimiento $(t)$ para mezclas fabricadas con CA 80-100 y CA 60-70

Figure 3. Evolution of vertical permanent deformation throughout ageing time $(t)$ for mixtures elaborated from CA 80-100 and CA 60-70 
Mixtures fabricated from CA 60-70 experiment a different behavior in comparison to those fabricated from CA 80-100 (see Figures $2 b$ and 3). During the first exposure months, the mixtures decrease their modulus by increasing permanent deformations. Afterwards such modulus is stabilized and finally there is an increasing tendency to decrease deformation values (especially when the test is developed at temperatures ranging from 20 to $30^{\circ} \mathrm{C}$ ). Probably the modulus decay is produced by micro-cracking generation, which appears at low temperatures when mixtures are too rigid (fragile behavior). Then those micro-cracking are stabilized and the stiffness increases due to an ageing and asphalt oxidative phenomenon similar to the one taking place in CA 80100 mixtures. Micro-cracking phenomenon at low temperatures has been widely studied by several researchers (e.g., Kliewer et al., 1996; Sebaaly et al., 2002; Nesnas and Nunn, 2006).

Water effect is not clear from observed results, since mixture humidity produces de-bonding between rock aggregate and asphalt; probably provoking a modulus decrease and mechanical resistance drop. Additional researchers in this field shall be conducted.

Figure 4 presents the relation $\left(E / E_{o}\right)$ between resilient modulus obtained after exposing briquettes under environmental conditions during different periods of time $(E)$ and, the initial mixtures resilient modulus for a period of $t=0$ months $\left(E_{o}\right)$. In the case of mixtures elaborated from CA 80-100, the modulus obtained from $t=48$ increases from 48 to $176 \%$, in relation to the initial modulus (depending on the temperature and frequency of the test). The most significant increment is observed as long as temperature increases in the test. CA 60-70 mixtures experiment a maximum modulus decrease of $35 \%$ during the first five months of exposure. However, after $t=47$ months, these mixtures increase and experiment modulus that slightly supersede the initial value. These results can be mathematically expressed by means of equations (3a) and (3b) for CA 80-100 and CA 60-70 asphaltic mixtures. This equation can only be employed for the analyzed mixture in the period of time under analysis (47-48 months), because the mixture behavior might change as long as $t$ increases. As well as in equation (1), in equation (3) the status variants k1-k3 are obtained by means of regressions and do not provide a defined physical meaning (see Table 8 ). 
Regression empirical equations that might reproduce the evolution of resilient modulus throughout time of exposure under environmental conditions, are enunciated in (4a) and (4b) for CA 80-100 and CA 60-70 mixtures, respectively. Such Equations are formulated based on the equations (1) and (3). Figure 4 presents the simulation of executed tests employing the equations $(4 a-b)$ and the correlation coefficient is $\mathbf{r}^{2}=0.79$.

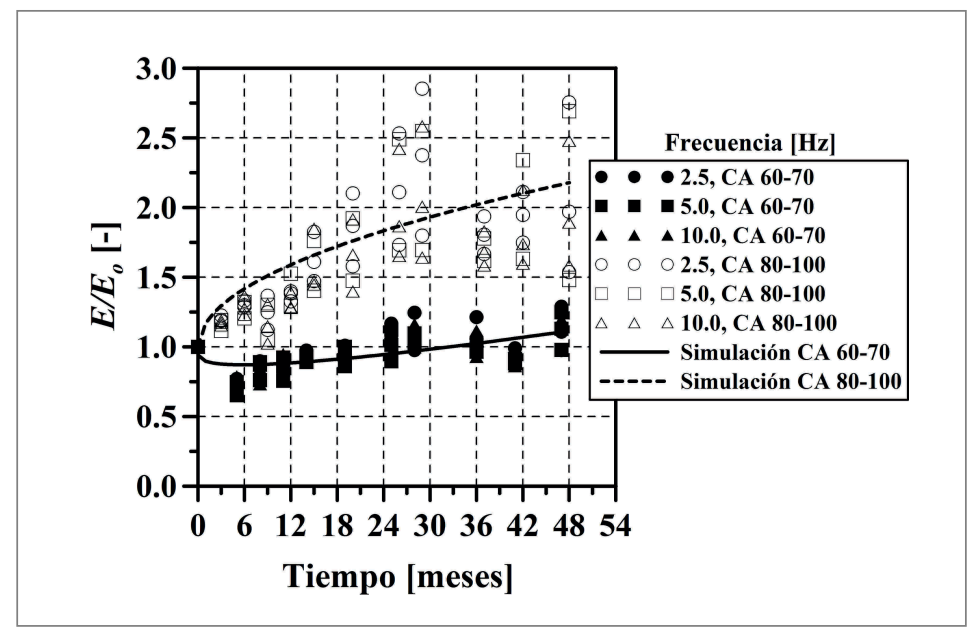

Figura 4. Evolución de la relación entre el módulo resiliente $(E)$ y el módulo inicial $\left(E_{O}\right)$ con el tiempo de envejecimiento (t) Figure 4. Evolution of relation between resilient modulus $(E)$ and initial modulus $\left(E_{o}\right)$ throughout ageing time $(\mathbf{t})$

$$
\begin{array}{cc}
\frac{E}{E_{o}}=1+k_{1} \sqrt{t} & \text { para/for CA 80-100 } \\
\frac{E}{E_{o}}=1-\left(k_{1}+k_{2} t+k_{3} \sqrt{t}\right) & \text { para/for CA 60-70 } \\
E=\left\{\exp \left(a+b T^{2}\right)+\left[\exp (c+d \sqrt{T})+\left(e+f T^{3}\right) \sqrt{F}\right]^{2}\right\}\left[1+k_{1} \sqrt{t}\right] & \text { para/for CA 80-100 } \\
E=\left\{\exp \left(a+b T^{2}\right)+\left[\exp (c+d \sqrt{T})+\left(e+f T^{3}\right) \sqrt{F}\right]^{2}\right\}\left[1-\left(k_{1}+k_{2} t+k_{3} \sqrt{t}\right)\right] & \text { para/for CA 60-70 }
\end{array}
$$

Tabla 8. Variables para simular la rigidez de la mezcla MDC-2 en función del tiempo de exposición al medio ambiente Tabla 8. Variants used to simulate mixture MDC-2 stiffness, in function of exposure time under environmental conditions

\begin{tabular}{||c|c|c|c|}
\hline CA & k1 & k2 & k3 \\
\hline $80-100$ & 0.17 & - & - \\
\hline $60-70$ & 0.058 & -0.012 & 0.058 \\
\hline
\end{tabular}


Figure 5a presents the results from fatigue testing developed on 360 samples of asphaltic concrete type MDC-1, MDC-3 and MDC-3. There is an amplitude value decrease $\varepsilon_{\max }$ (deformation amplitude for material failure when $N_{f}$ load cycles are applied) as long as resilient modulus is incremented in mixtures $(E)$, which is equivalent to the status where the material is changing its behavior from ductile to fragile due to stiffening. These results can be mathematically represented by means of Equation (5). This equation was chosen taking into consideration that for a very low level of deformation amplitude applied on the material, it can endure such amplitude infinite times without rupturing (concept of fatigue endurance limit stated by Carpenter et al., 2003 and Reyes, 2003). Status variant values in the equation (5) were determined by means of regression: $k_{4}=6.24 \times 10$ $6, k_{5}=0.48$ and $k_{6}=15.79$. Similar results as the ones found in this research were reported by Schmidt and Santucci (1969). Although material allows lower tensile deformations as long as it stiffens, fatigue-life or the number of cycles required for material failure $\left(N_{f}\right)$ increases, as described by equation (6) (see figure 6). Such results are in accordance with those reported by the referred biography.

$$
\varepsilon_{\max }=k_{4}+\frac{k_{5}}{E}+\frac{k_{6}}{E^{3 / 2}}
$$

$$
N_{f}=4.74\left(\frac{\sigma}{E}\right)^{-2.96} 10^{0.165}
$$

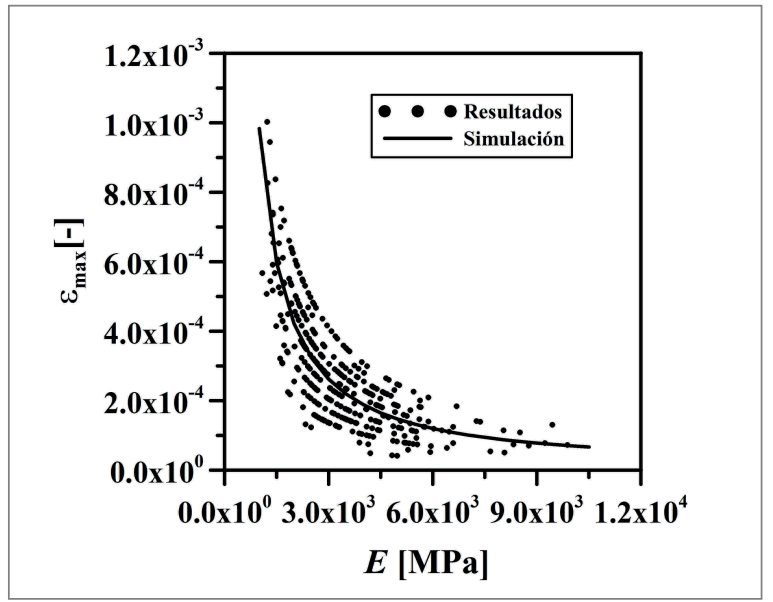

Figura 5. Evolución de $\varepsilon_{\max } \operatorname{con} E$

Figure 5. Evolution of $\varepsilon_{\max }$ with $E$ 


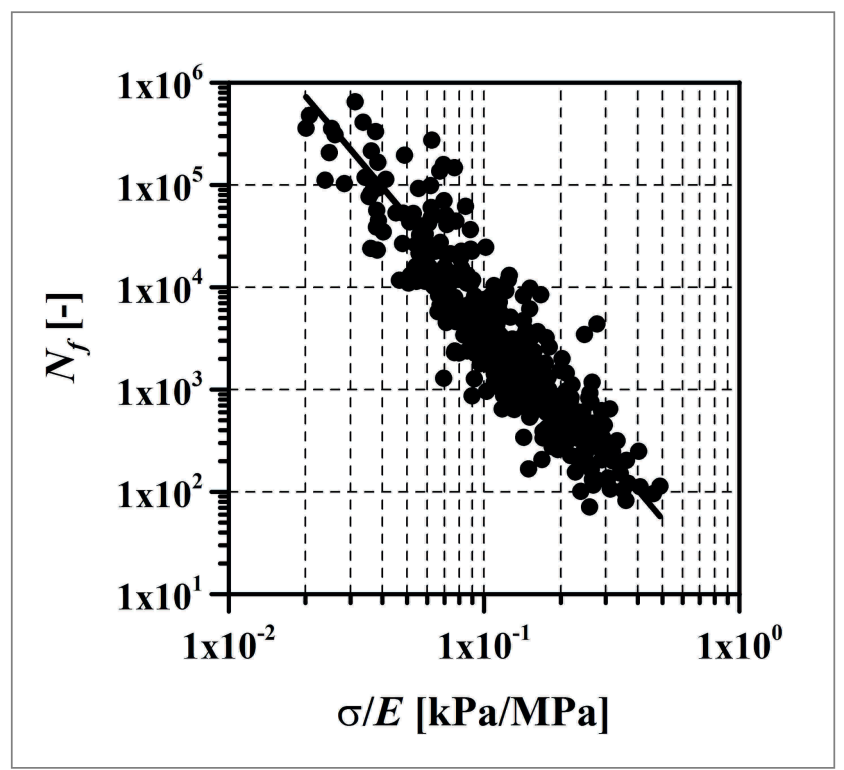

Figura 6. Evolución del número de ciclos de falla con $\sigma / E$

Figure 6. Evolution of number of failure cycles with $\sigma / E$

If equations (4-5) are fused, the evolution experimented by ? max with the evolution of mixtures stiffness exposed to environmental conditions in Bogota D.C. are obtained. By using these equations it is possible to predict that acceptable tensile deformation of the mixture will decrease from $t_{\text {inicial }}=\mathbf{0}$ up to $t=29$ months, from 55 to $64 \%$, only due to the effect of increased stiffness during exposure to environmental conditions in Bogota D.C. In the same way, during the same period of time the equation (6) reports an average increase of fatigue-life 6.85 times higher, due to the mixture stiffening effect. From $t=30$ up to $t=48$ months, stiffening effect decreases and the mixture will experiment a fatigue-life increase of 10 times, due to stiffening from $t_{\text {inicial }}=\mathbf{0}$ up to $t_{\text {inicial }}=48$ months.

The analysis of fatigue-life for CA 60-70 mixtures is far more complex, since during the first exposure months under environmental conditions, stiffness drops in an average of $12.8 \%$ causing a reduction of $33 \%$ in the mixture fatigue-life. However, between $t=5$ and $t_{\text {final }}=\mathbf{4 7}$ months, it reappears and increases stiffness, thus generating at the end of exposure time a slight average increment of fatigue-life of $38 \%$ in comparison to $t_{\text {inicial }}=\mathbf{0}$ months. 


\section{Conclusions}

This study conducted a development phase intended to measure the influence of climatic conditions in Bogota D.C, on the stiffness and fatigue-life of an asphaltic concrete mixture type MDC-2 elaborated from asphaltic cement type CA 80-100 and CA 60-70. From obtained results it is concluded that resilient modulus of the CA 80-100 mixture increases an average of 2.17 times, during 48 months of exposure under environmental conditions. Such stiffness increase generates an increment of approximately 10 times in mixture fatigue-life, only because of asphaltic binder stiffening effect, due to its own ageing condition. In the case of CA 60-70 mixtures, the increment of fatigue-life during 47 exposure months was only of $38 \%$, since during the first 5 months such property decreased probably due to thermal microcracking endured by the mixture at low temperatures. The mixtures stiffness increment created an obvious endurance increase against rutting phenomenon.

Fatigue results previously introduced are valid provided that the analyzed mixture is made of thick asphaltic layers, where controlled stress is the loading mode. These results are also valid for pavements exposed only under environmental conditions and during the analyzed period of time. Presently the research group is jointly evaluating the loading effects, the modification of binder chemical composition and the environmental conditions to clearly understand the evolution of damage mechanisms on asphaltic layers.

\section{Referencias / References}

AASHTO (1993), American Association of State Highway and Transportation Officials, Guide for design of pavement structures. Washington, D.C.

Airey G. D. (2003), State of the art report on ageing test methodgs for bituminous pavement materials. International Journal of Pavement Engineering, Vol. 4, No 3, 165-176.

Austroads (1992), Pavement design, a guide to the structural design of road pavement. Austroads, Sydney, Australia. Bishara S. W., Robertson R. E. and Mahoney D. (2000), Rapid oxidative aging of binder using microwave energy - an improved method. In Proc. 2nd Eurasphalt and Eurobitume Congress, Session 2: Development in Bituminous Products and Techniques, (Barcelona), 27-36.

Bocci M. and Cerni G. (2000), The ultraviolet radiation in short-and long-term aging of bitumen. In: Proc. 2nd Eurasphalt and Eurobitume Congress, Session 1: Performance Testing and Specifications for Binder and Mixtures (Barcelona), 49-58. Brown S. F. and Scholz T. V. (2000), Development of laboratory protocols for the ageing of asphalt mixtures. In: Proc. 2nd Eurasphalt and Eurobitume Congress, Session 1: Performance Testing and Specifications for Binder and Mixtures, (Barcelona), 83-90. 
Carpenter S. H., Ghuzlan K. A. and Shen S. (2003), Fatigue endurance limit for highway and airport pavement. Transportation Research Record (TRR): Journal of the Transportation Research Board, No. 1832, TRB, National Research Council, Washington D.C, 131-138.

CEN (2005), Committee European of Normalization. Bituminous Mixture Test Methods for Hot Mix Asphalts - Part25: Cyclic Compression Tests.

Choquet F. S. and Verhasselt A. F. (1992), Natural and accelerated ageing of bitumens - effects on the asphaltenes. In: Proc. of an International Symposium on Asphaltene Particles in Fossil Fuel Exploration, Recovery, Refining and Production Processes, Ed. MK Sharna and TF Yen 1994, Plenum Press, New York, 13-29.

Di Benedetto H. and De la Roche C. (2005), State of the art on stiffness modulus and fatigue of bituminous mixtures. Report RILEM No. 17 Bituminous binders and mixes: State of the art and interlaboratory test on mechanical behavior and mix design, L. Francken, ed., E and FN Spon, London, 2005, pp. 97-123.

Di Benedetto H., De la Roche C., Baaj H., Pronk,A. and Lundstrom R. (2004), Fatigue of bituminous mixtures. Material and Structures, Vol. 37, No. 4, 202-216.

Epps J. A. (1969), Influence of mixture variables on the flexural fatigue and tensile properties of asphalt concrete. Ph. D. thesis, University of California, Berkeley, Calif.

Epps J. A. and Monismith C. L. (1972), Fatigue of asphalt concrete mixtures - summary of existing information. Fatigue of Compacted Bituminous Aggregate Mixtures, ASTM STP 508, American Society for Testing and Materials, 19-45.

González L. A. and Vásquez S. E. (2009), Estado del conocimiento sobre el fenómeno de fatiga en mezclas asfálticas. Tesis de pregrado, Universidad Católica de Colombia, Bogotá D.C. (Colombia).

Harvey J. and Tsai B.-W. (1997), Long-term oven aging effects on fatigue and initial stiffness of asphalt concrete. Transportation Research Record (TRR): Journal of the Transportation Research Board, No. 1590, 89-98.

HMSO (1994), DMRB-Design Manual for Roads and Bridges. Vol. 7, HD 25/94, part 2, Foundations. Instituto de Desarrollo Urbano y Universidad de Los Andes. (2002). Manual de Diseño de Pavimentos para Bogotá. Bogotá D.C., Colombia.

INVIAS (2007), Instituto Nacional de Vías. Especificaciones Generales para Construcción de Carreteras. Bogotá D.C., Colombia. INVIAS (2007a), Instituto Nacional de Vías. Normas de Ensayos de Materiales para Carreteras. V. I y II. Bogotá D.C., Colombia. Jemison, H. B., Davison, R. R., Glover, C. J. and Bullin, J. A. (1991). Evaluation of standard oven tests for hot-mix plant aging. Transportation Research Record, 1323, Transportation Research Board, Washington D.C., $77-84$.

Kemp G. R. and Predoehl N. H. (1981), A comparison of field and laboratory environments of asphalt durability. Proc. Assn. Asphalt Paving Technol., 50, 492-537.

Khalid H. A. (2002), A new approach for the accelerated ageing of porous asphalt mixtures. Proceedings of the Institution of Civil Engineers, Transport 153, Issue 3, 171-181.

Khalid H. A. and Walsh C. M. (2000), Relating mix and binder fundamental properties of aged porous asphalt materials. In: Proc. 2nd Eurasphalt and Eurobitume Congress, Session 1: Performance Testing and Specifications for Binder and Mixtures (Barcelona), 398-405.

Kim O-K., Bell C. A., Wilson J. E. and Boyle G. (1987), Development of laboratory oxidative aging procedures for asphalt cements and asphalt mixtures. Transportation Research Record, 1115, Transportation Research Board, Washington D.C., 101-112.

Kliewer J. E., Zeng H. and Vinson T. S. (1996), Aging and low-temperature cracking of asphalt concrete mixture. Journal of Cold Regions Engineering, Vol. 10, No. 3, 134-148.

Kuppens E. A. M., Sanches F., Nardelli L. and Jongmans E. C. (1997), Bitumen-ageing tests for predicting durability of porous asphalt. In: Di Benedetto, H., Francken, L., Proc. Fifth International RILEM Symposium, Mechanical Tests for Bituminous Materials, 71-77.

Lin X. X. A (1989), Method of Determining the Relevant Parameters in the Calculation of Pavement Deformation of Bituminous Surface. China J. Highway and Transport, No. 2, 10-20.

Lin X. X. (1989a), Study on Semi-Rigid Asphalt Pavement. Rep. of Key Sci. and Tech. Projects 85-65, Ministry of Communications, Beijing.

MEPDG. ARA, Inc. ERES Consultants Division (2004), Guide for the Mechanistic-Empirical Design of New and Rehabilitated Pavement Structures. NCHRP Project 1-37A, Transportation Research Board, Washington, D.C., www.trb.org/mepdg/. Accessed September 12 of 2007.

Migliori F. and Corté J-F. (1998), Comparative study of RTFOT and PAV aging simulation laboratory tests. Transportation Research Record, 1638, Transportation Research Board, Washington D.C., 56-63.

Montepara A. (1999), A theoretical-interpretative model of the relationship between UV-radiation ageing of bitumen and viscosity variation. In: Proc. of Eurobitume Workshop, paper No. 075, Luxemburg.

Montepara A. and Giuliani F. (2000), Comparison between ageing simulation tests of road bitumen. In: Proc. 2nd Eurasphalt and Eurobitume Congress, Session 1: Performance Testing and Specifications for Binder and Mixtures, (Barcelona), 518-523. 
Nesnas K. and Nunn M. E. (2006), A thermal pavement response model for top-down reflection cracking in composite pavements. In 85th Annual Meeting of the Transportation Research Board, paper No. 06-0127, Washington, D.C., January 2006. Rao Tangella R., Craus J., Deacon J. A. and Monismith C. L. (1990), Summary report on fatigue response of asphalt mixtures. Rep. to Strategic Highway Research Program, Washington, D.C.

Reyes F. A. (2003), Diseño Racional de Pavimentos. Escuela Colombiana de Ingeniería, 1ra. Edición, Bogotá D.C., Colombia.

Said S. F. (2005), Aging effect on mechanical characteristics of bituminous mixtures. Transportation Research Record: Journal of the Transportation Research Board, 1901, Washington D.C., 1-9.

Schmidt R. J. and Santucci L. E. (1969), The effect of asphalt properties on the fatigue cracking of asphalt concrete on the ZacaWigmoretest Project. In: Proceedings, Association of Asphalt Paving Technologists, PRPTA, Vol. 38, $39-64$.

Sebaaly P. E., Lake A. and Epps J. (2002), Evaluation of low-temperature properties of HMA mixtures. Journal of Transportation Engineering, Vol. 128, No. 6, 578-586.

SHELL (1978), International Petroleum Company. Shell Pavement Design Manual, Asphalt Pavement and Overlays for Road Traffic. London (U.K.).

Shen J., Amirkhanian S. and Tang B. (2006), Influence of accelerated aging test temperature on the properties of binders. International Journal of Pavement Engineering, Vol. 7, Issue 3, 191-198.

Shiau J-M., Tia M., Ruth B. E. and Page G. C. (1991), Characterization of age-hardening potential of asphalt by using CorbettSwarbrick asphalt fractionation test. Transportation Research Record, 1323, Transportation Research Board, Washington D.C., 53-60.

TAI-The Asphalt Institute (1982), Research and Development of the Asphalt Institutes Thickness Design Manual. MS 1, 9th Ed. College Park, Md.

TRL-Transport Research Laboratory (1993), A guide to the structural design of bitumen surfaced roads in tropical and subtropical countries. Draft 4th edition.

Verhasselt A. F. (1997), Field ageing of bituminous binders: simulation and kinetic approach. In: Di Benedetto, H., Francken, L., Proc. Fifth International RILEM Symposium, Mechanical Tests for Bituminous Materials, 121-128.

Welborn J. Y. (1984), Physical properties as related to asphalt durability: state of the art. Transportation Research Record, 999, Transportation Research Board, Washington D.C., 31-36. 